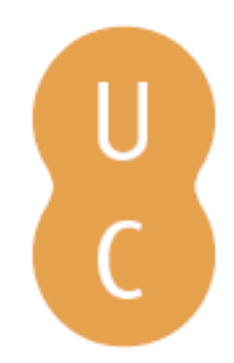

\title{
nommalina
}

\section{El agua primordial, entre el mito y la filosofía}

\author{
Autor(es): $\quad$ Bernabé, Alberto
}

Publicado por: Imprensa da Universidade de Coimbra

URL

persistente: URI:http://hdl.handle.net/10316.2/45095

DOI: $\quad$ DOI:https://doi.org/10.14195/978-989-26-1568-4_1

Accessed : $\quad$ 26-Apr-2023 16:23:41

A navegação consulta e descarregamento dos títulos inseridos nas Bibliotecas Digitais UC Digitalis, UC Pombalina e UC Impactum, pressupõem a aceitação plena e sem reservas dos Termos e Condições de Uso destas Bibliotecas Digitais, disponíveis em https://digitalis.uc.pt/pt-pt/termos.

Conforme exposto nos referidos Termos e Condições de Uso, o descarregamento de títulos de acesso restrito requer uma licença válida de autorização devendo o utilizador aceder ao(s) documento(s) a partir de um endereço de IP da instituição detentora da supramencionada licença.

Ao utilizador é apenas permitido o descarregamento para uso pessoal, pelo que o emprego do(s) título(s) descarregado(s) para outro fim, designadamente comercial, carece de autorização do respetivo autor ou editor da obra.

Na medida em que todas as obras da UC Digitalis se encontram protegidas pelo Código do Direito de Autor e Direitos Conexos e demais legislação aplicável, toda a cópia, parcial ou total, deste documento, nos casos em que é legalmente admitida, deverá conter ou fazer-se acompanhar por este aviso.

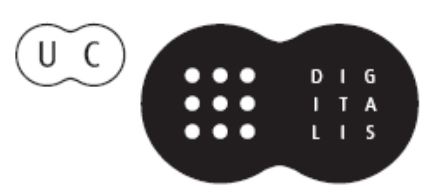




\section{O melhor é a água}

\section{Da antiguidade clássica aos}

nossos dias

José Luís Brandão \& Paula Barata Dias (coords.) 


\section{Prefácio}

Talvez nunca, como nos nossos dias, tenha sido tão aguda a consciência de que a água é um recurso finito que urge proteger. Nestes dois últimos séculos registaram-se, globalmente, formas acrescidas de poluição, aumento demográfico e alterações climáticas, que se manifestam em períodos de seca extrema alternados com tempestades incontroláveis e terríveis incêndios estivais que deixam fragilizados os nossos ecossistemas e modos de vida diante da extrema preciosidade e, ao mesmo tempo, vulnerabilidade desse elemento vital que é a água: bem precioso a usar conscientemente, a defender, a guardar e a celebrar.

Constatamos, no entanto, que a consciência do valor da água não é de hoje. A história da humanidade, a cultura material e tecnológica das civilizações, a linguagem e os rituais religiosos, as expressões artísticas e, entre estas, sumamente a literatura disso deram conta, mostrando como a água era valorizada no seu uso e nas suas funções, mas também na sua essência de elemento constitutivo do cosmos envolvente.

Este volume propõe-se, pois, apresentar múltiplas leituras da água, desde a sua utilização concreta e material à dimensão simbólica, metafórica e imaterial: seja como elemento primordial associado à criação do mundo; como símbolo e fonte de vida ou, paradoxalmente, gerador de morte, como cenário lúdico e espaço de lazer, como elemento constituinte de rituais, mas também como via de comunicação ou de separação entre as gentes, como meio e vestígio de civilização e elemento estruturante e promotor da cidade enquanto modo complexo de organização das comunidades humanas. Por isso, a água vai jorrando através dos textos filosóficos e religiosos, da poesia, da dramaturgia, das fontes histórico-biográficas e arqueológicas, tanto na antiguidade como na receção humanista e contemporânea. Trata-se, portanto, de contributos de estudiosos de vária proveniência e de áreas diversas (filosofia, línguas e literaturas, história, arqueologia) que aceitaram partilhar os seus conhecimentos e reflexões sobre as marcas que a água deixou, quer no pensamento antigo e moderno quer em estruturas urbanas moldadas pelo homem.

A água como elemento primordial (tema da parte I) figura, como é sabido, nos relatos míticos e religiosos, bem como nas preocupações dos filósofos pré-socráticos. Tal interrogação sobre as origens ecoa igualmente em numerosos desenvolvimentos literários matriciais. Assim, Píndaro propiciou, desde o início, papel de relevo como um motivador desta obra, pela sua enigmática abertura da Olimpica 1, com a expressão "o melhor é a água", da qual a publicação tira o lema, seja a interpretação para este estatuto primordial cosmológica, metáfora da poesia do autor, ou simplesmente a expressão da força daquele elemento como 
gerador e suporte de vida. E ideia semelhante parece estar presente na cosmogonia implícita na Nemeia 8.

Mas o outro eixo fundacional que integra o nosso património é o valor destruidor, purificador e regenerador que se atribui à água na cultura judaica e cristã, alicerçada sobre os textos bíblicos, de onde se destacam pelo seu simbolismo e pelo diálogo intertextual, os relatos da criação, do dilúvio, da passagem do Mar Vermelho, do batismo de Jesus e de uma série de milagres associados à água. Assim a cultura clássica e a judaica e cristã caminham lado a lado na conceção do papel da água na génese do mundo e nas matrizes culturais que nos orientam.

A literatura está pejada de evocações de espaços da água. Propomos, pois, a exemplificação da força simbólica de ambientes aquáticos (parte II) em alguns autores gregos e latinos e em contextos complementares. Se o género dramático possibilita a exploração do valor simbólico da água e pressupõe a sua plasticidade em contexto de representação, a epopeia enquadra por tradição o mar como elemento de ligação ou de separação de povos e culturas, metáfora da viagem transformadora, mas também geradora de medos decorrente da partida para o desconhecido por sobre abismos e perigos inesperados. Um dos espaços presentes é, pois, o mar, que no Édipo Rei de Sófocles é evocado no sentido mais negativo pelo seu lado tempestuoso, metáfora dos males que assolam a nau do Estado de Tebas, mas que, no Édipo em Colono, remete, pela sua imensidão, para um lugar intemporal sagrado, representado na obra pelo templo de Posêidon. Já a presença física da água no espaço de representação da Lisístrata de Aristófanes, onde se impõe sobre o fogo, representará a vitória idealizada das mulheres na luta que as opõe aos homens neste tratamento cómico das motivações da guerra do Peloponeso.

No que respeita à épica, a riqueza e variedade do léxico significativo de mar na Eneida de Virgílio revela a reflexão e criatividade do poeta na descrição de um ambiente que ocupa sobretudo a parte odisseica da obra. A ligação entre descrição de espaços naturais da água e ethos é visível na enciclopédia sobre a natureza, Naturales Quaestiones, de Séneca, cuja descrição dos cenários grotescos não deixa de fazer transparecer uma intenção moralizadora.

A água, enquanto fonte de vida, está intimamente ligada ao desenvolvimento da cidade (Parte III), antes de mais pelas estruturas relacionadas com as necessidades básicas dos cidadãos, mas também com rituais religiosos, pela função lustral, e com a componente lúdica, pela plasticidade. Fazia parte do evergetismo dos governantes a oferta de jogos, como as naumaquias, que fizeram as delícias do público romano em anfiteatros adaptados, em lagos abertos para o efeito ou em cenários naturais: espetáculos de propaganda e poder, onde divertimento e punição andaram amiúde de mãos dadas e em que água aparece associada também à morte.

Tais expedientes e, antes de mais, as necessidades básicas dos cidadãos implicam um cuidado e desenvolvido sistema de fornecimento de água. $\mathrm{O}$ estudo 
deste aspecto aplicado a um núcleo urbano concreto, suscita diversas perspectivas de análise (jurídica, científica, administrativa, urbanística, ideológica, arqueológica, geográfica, hidrográfica, económica) e evoluídos trabalhos de engenharia. Um estudo de caso considerado, o de Bracara Augusta, implica a análise diacrónica e funcional dos espaços (termas, aquedutos e recintos funerários). Outro estudo de caso, apresenta os passos e reviravoltas da construção moderna, nunca terminada, do aqueduto de Santa Clara, na cidade do Mondego, truncado recentemente por outra obra de engenharia contemporânea: um lanço de estrada.

A tradição clássica sobre o tema recebe ecos e desenvolvimentos originais entre os humanistas e autores contemporâneos (Parte IV), que em antigos géneros cultivam novos temas e antigos temas em novos géneros. Disto é exemplo Manuel da Costa no epitalâmio Proteu que celebra o enlace do príncipe João e da princesa Joana, onde o mar ocupa lugar de destaque e as divindades aquáticas sugerem a abertura a novos mundos propiciada pelas descobertas. $\mathrm{E}$ as divindades aquáticas do mundo clássico são ainda evocadas como favoráveis em contexto cristão no poema épico novilatino Paciecidos libri duodecim da autoria do jesuíta Bartolomeu Pereira, onde se celebra a vida e o martírio do Padre Francisco Pacheco, queimado vivo em Nagasaki juntamente com oito companheiros.

E, porque "tudo flui", o percurso encerra-se com a evocação da água em Vergílio Ferreira, nas memórias do protagonista de Em nome da terra, que lhe propiciam um regresso lustral a uma pujante juventude passada e uma fuga ao cárcere do corpo presente que já não obedece, mas também no aconchego íntimo e melancólico suscitado amiúde pela chuva nos Diários do autor, ou no irrefreável jorrar da sua própria escrita...

Portanto, que este percurso panorâmico aqui apresentado ao longo das muitas vozes que, conforme várias tipologias discursivas, se pronunciaram sobre a identidade, a função e o uso da água, integre e acompanhe com perfeito propósito, a nossa atualidade informativa e académica, a que nos devolve, de modo objetivo e sustentado, a centralidade da água no equilíbrio cósmico e ecológico do planeta e na qualidade da vida dos homens.

Os Coordenadores José Luís Brandão Paula Barata Dias 


\title{
El AGUA PRIMORDIAL, ENTRE EL MITO Y LA FILOSOFÍA (Primordial Water, Between Myth And Philosophy)
}

\author{
Alberto Bernabé (albernab@filol.ucm.es) \\ Universidad Complutense de Madrid \\ orcid.org/0000-0002-7228-735X
}

\begin{abstract}
Resumen - El agua ha sido reiteradamente considerado elemento que se encuentra en el origen de todo e incluso la materia de la que todo está constituido. El propósito del artículo es pasar revista a los relatos griegos más antiguos sobre el origen del mundo que le atribuyen al agua un papel primordial, para señalar las distintas formas en que se describe el proceso en que interviene y la gran diversidad de detalles que diferencian unos de otros. Se analizan las propuestas míticas desde la épica arcaica a las teogonías órficas del s. II a. C. y las filosóficas de los presocráticos.

Palabras clave - agua primordial, cosmogonías, épica arcaica, poemas órficos, filósofos presocráticos.
\end{abstract}

Авsтract - Water has been repeatedly considered as an element found at the origin of all things, and even as the matter from which all things are made. The aim of this paper is to review the oldest Greek accounts of the world's origin that attribute a primordial role to water, so as to highlight the different ways in which the cosmogonical process is presented, and the great diversity of details that differentiate them. Mythical proposals from archaic poetry to orphic theogonies of the $2 \mathrm{nd}$. cent. BCE, and philosophical proposals of the presocratic philosophers are analyzed.

KEYwords - primordial water, cosmogonies, archaic epic, orphic poems, presocratic philosophers.

\section{InTRODUCCIón}

"Lo mejor, el agua". Con esa frase lapidaria, que puede significarlo casi todo, inicia Píndaro una de sus Odas más hermosas: la Olímpica I. El agua, elemento fundamental para la vida, ha sido también reiteradamente considerada materia primordial, el elemento que se encuentra en el origen de todo e incluso la materia de la que todo está constituido. Mi propósito en este artículo es pasar revista, aunque sea de modo rápido, a los relatos griegos más antiguos sobre el origen del mundo que le atribuyen al agua un papel primordial, para señalar las distintas formas en que se describe el proceso en que interviene y la gran diversidad de detalles que diferencian unos de otros. Para ello, pienso que, antes que nada, merece la pena adelantar las variables en las que fijaré la atención para articular mi exposición.

La primera variable es si el relato en que se inserta la referencia al agua 
primordial es una propuesta literaria y mítica, o filosófica y científica. En este caso hay, sin embargo alguna interesante precisión que hacer. Las propuestas míticas y las filosóficas no han seguido líneas separadas, sino que se han producido interrelaciones entre un ámbito y el otro. Es más, frente a otros temas en los que los mitos han influido sobre los textos filosóficos, pero no ha ocurrido lo contrario, en el caso de las referencias al agua primordial, los influjos se han producido en ambas direcciones y de formas variadas. Está claro que las primeras formulaciones filosóficas se han basado en las míticas, pero también lo está que en relatos míticos tardíos se advierte una fuerte influencia filosófica e incluso hay un aspecto muy peculiar: hay casos en que determinados filósofos han interpretado more philosophico propuestas míticas antiguas.

En segundo lugar es pertinente si el agua se considera un ente divino o simplemente material, aunque a menudo esta sea también una cuestión difícil de dilucidar.

La tercera variable que debe atenderse es si en la propuesta en cuestión el agua es la única materia originaria o se postula más de una, entiéndase en pie de igualdad con ella y no derivada de ella.

La cuarta variable es si en el modelo propuesto el agua se considera solo origen de los seres vivos o, a un nivel más alto, de la totalidad de las cosas que son. El problema es que a menudo no es fácil determinar el papel preciso que se le atribuye al agua en una afirmación descontextualizada como es un fragmento.

La quinta variable es si se propone que el agua es capaz de generar cambios per se o si es afectada por un motor externo a la hora de generar la multiplicidad del mundo.

Mi indagación, en el caso del mito, se limitará al período de tiempo que se extiende desde la épica arcaica, siglos VIII-VII a. C., a las teogonías órficas más recientes; en torno al s. II a. C. En el caso de la filosofía, se confinará a los filósofos presocráticos, un marco que solo excederé en el caso de las interpretaciones filosóficas de las teogonías míticas. Ni que decir tiene que no pretendo ser exhaustivo. Téngase en cuenta que Rudhardt dedicó solo a la cuestión de las propuestas míticas sobre el agua primordial una magnífica monografía de más de cien páginas ${ }^{1}$.

\section{LAS PRIMERAS PROPUESTAS MÍTICAS Y SUS POSIBLES ORÍGENES ORIENTALES}

\subsection{Océano y Tetis en Homero}

Pese a que los poemas de Homero se ocupan de cuestiones muy lejanas de las preocupaciones cosmogónicas, encontramos un par de referencias de pasada a una pareja primordial, que parecen ser el reflejo de un antiguo mito de orígenes.

\footnotetext{
${ }^{1}$ Rudhardt 1971.
} 
En la primera de ellas Hera le anuncia a Zeus:

Pues voy a los confines de la tierra que a muchos alimenta, a ver

a Océano, nacimiento de dioses, y a la madre Tetis.

(Hom. Il. 14.200-201 14.301-203)

Como es sabido, Océano es considerado por los griegos un río que circunda la tierra (por ello Hera debe ir a verlo a los confines de la tierra, cf. Hom. Il. 18.607, 21.194). Por otra parte, al ser considerado un río, se entiende que las aguas que lo componen son dulces.

Por su parte, Tetis (Tethys) es un personaje con un papel mínimo en las historias de los dioses. Para dilucidar su naturaleza debemos avanzar en el tiempo hasta el s. IV a. C., en que Licofrón usa su nombre como metonimia por el mar:

donde hacia la Tetis de Lampeta

el cuerno de Hiponio, duro, está inclinado (Lyc. 1068-1070).

Como indica el escolio ad loc.,

"Hacia la Tetis" se dice por "hacia el mar" y "cuerno" es "promontorio"

La mención de Licofrón parece indicar que el erudito autor conocía una tradición más antigua, que vinculaba a esta divinidad con las aguas saladas.

Volviendo al texto homérico, genesis es una palabra que en los textos antiguos se reserva al nacimiento de seres cosmogónicos y dioses ${ }^{3}$. Tal calificación, unida a la de Tetis como "madre" evidencian que Océano y Tetis son descritos como los padres primordiales de todos los dioses.

Océano vuelve a ser presentado en este papel primordial en otro pasaje de la Ilíada, en el que es mejor entender pantessi como "de todas las cosas" y no solo "de todos (los dioses)":

Océano, que es el origen de todas las cosas (Hom. Il. 14.246).

Por último, pocos versos después del primero de los pasajes citados, Hera añade:

\footnotetext{
${ }^{2}$ Cf. asimismo AP 7.214.6 (Archias), Nonn. D. 31.187, Orph. Arg. 335.

${ }^{3}$ Cf. Diccionario griego español en línea (http://dge.cchs.csic.es/xdge/), s. v. genesis.
} 
Voy a verlos, por si puedo resolver sus constantes querellas,

pues hace ya mucho tiempo que se han separado el uno de la otra, sin lecho y sin amor (Hom. Il. 14.205-207 = 14.304-306).

Burkert, siguiendo algunas propuestas más antiguas ${ }^{4}$ hace verosímil que el mito griego de Océano y Tetis fuera una adaptación de un mito babilonio que conocemos por el comienzo del Enuma Elish, un poema babilonio conservado en tablillas de la Biblioteca de Assurbanipal, es decir, del siglo VII a.C. en la redacción que tenemos. En este mito se cuenta que Apsu, el agua dulce, y Tiamat, el agua salada, son la pareja primordial, cuya separación dará lugar al mundo diversificado 5 . Incluso, el nombre de Tetis puede ser una adaptación griega de uno de los nombres que recibe Tiamat en el Enuma Elish: taw(a)tu. Asimismo señala Burkert que el Enuma Elish era conocido en Grecia. En efecto, en el siglo IV a.C. se refiere a él un discípulo de Aristóteles:

De los bárbaros, parece que los babilonios ... consideraron dos (principios), Taute (i.e. Tiamat) y Apason (i.e. Apsu), considerando a Apason esposo de Taute y llamando a esta madre de los dioses

(Eudem. 150 Wehrli).

\subsection{La indignación de Menelao}

Por otra parte, encontramos una curiosa afirmación en la Ilíada, en boca de un defraudado Menelao:

Pues ojalá todos vosotros os convirtierais en agua y tierra (Hom. Il. 7.99).

Se he reiterado la idea de que Menelao quiere decir "ojalá os murierais y volvierais así a convertiros en las materias de las que estáis compuestos”, pero, si bien es cierto que la idea de que los seres humanos están hechos de barro está presente en diversos autores, como veremos más adelante, ello no quiere decir que debamos considerar que está en la base de esta frase de Homero. Dado que no hay un adverbio como palin u otro sinónimo que significara "de nuevo" y que indicara inequívocamente que ojalá volviérais "de nuevo” a ser agua y tierra, Menelao puede querer decir tan solo que unos combatientes carentes de valor merecen convertirse en cosas inertes.

${ }^{4}$ Burkert 1992: 91-96; cita como antecedente a Gladstone 1890: appendix y añade más bibliografía en $202 \mathrm{n} 14$.

${ }^{5}$ King 1902, Lambert y Parker 1966, Cunchillos 1990, Lara Peinado 2008. 


\subsection{Un modelo alternativo: Hesíodo}

Hesíodo, por su parte, presenta una cosmogonía en la que se decanta por un modelo distinto del de Homero:

Pues bien lo primerísimo se generó Caos, pero enseguida

Tierra (Gaia) de ancho pecho ...

y el Tártaro nebuloso, en la entraña de la Tierra de anchos caminos ...

Tierra generó lo primero, igual a sí misma

a Cielo (Ouranos) estrellado ...

Ella dio a luz a los grandes montes...

parió asimismo al mar que no puede secarse, que se embravece en olas,

a Ponto, sin el deseable amor, pero enseguida

unida en amor a Cielo, parió a Océano de profundos remolinos

(Hes. Th. 116ss.).

Para Hesíodo, lo primigenio es Caos, que por la etimología y por otros motivos sabemos que era una abertura ${ }^{6}$ que da lugar a la Tierra, con un abismo bajo ella, el Tártaro, y al Cielo, arriba, aunque las necesidades narrativas de Hesíodo le hacen presentar este segundo hecho en una etapa sucesiva. Las aguas tienen en su propuesta una importancia menor. Primero, aparece Ponto, como una especie de "excrecencia" de Tierra, al mismo nivel que los montes y, mientras que la pareja Cielo y Tierra asumen luego el protagonismo del mito, Océano y Tetis desempeñan en él un papel muy marginal; Océano es para Hesíodo uno de los seis Titanes nacidos de Urano y Gea y Tetis una de las seis Titánides hermanas suyas. Más adelante (Hes. Th. 337-370) la estirpe de ambos se reduce a los grandes ríos y las innumerables Oceánides. Quedan, pues, relegados a los espacios acuáticos y a un papel de muy escasa importancia.

\subsection{Pandora y la creación de seres humanos a partir del barro}

Una breve alusión merece la presencia en Hesíodo de una huella del mito que hace proceder a los hombres de figuras modeladas en barro. Cuenta que Pandora fue modelada por Hefesto, porque Zeus, irritado contra Prometeo,

Ordenó al muy ilustre Hefesto que cuanto antes mezclara tierra con agua (Hes. OD 60-61).

Hesíodo reduce este mito del origen a partir de figuras modeladas en barro a la primera mujer (no dice nada sobre el origen de los hombres), pero hay muchos ecos en la literatura griega de la creencia en que los hombres en general proceden

\footnotetext{
${ }^{6}$ Un buen estado de cuestión en Martínez Nieto 2000: 40-52.
} 
del barro. Además del caso de Jenófanes, sobre el que volveré, hay otros muchos: Aristófanes en las Aves hace la parodia de una epifanía divina, de esas en las que los dioses insultan a los mortales, aunque en este caso son las aves las que lo hacen. El insulto consiste en llamar a los seres humanos "figurillas de barro" (Ar. Av. 686). Un epigrama anónimo (GVI 1702. 2) pone en boca de un difunto lo que parece ser una creencia relativamente común: "nacido de la tierra, me torné en tierra de nuevo". Asimismo, un conocidísimo texto del Génesis (2.7) es una traducción del texto hebreo, más o menos adaptada al imaginario de los griegos: "Entonces modeló Dios (Yahveh Elohim) al hombre (adam) del polvo del suelo (adamah) e insuflando en sus narices aliento de vida, quedó constituido el hombre como alma viviente".

\subsection{Océano y Tetis en la Teogonía órfica llamada "Eudemia"}

En el trascurso de sus disertaciones etimológicas en el Crátilo, Platón introduce con un displicente "dice Orfeo por alguna parte" una cita de dos versos que hacen referencia de nuevo a la pareja Océano-Tetis, esta vez como "iniciadores de las bodas":

Océano de hermosa corriente inició las bodas;

él que se unió a Tetis, su propia hermana de la misma madre

(Pl. Crat. 402b = Orph. fr. 22 I Bernabé).

En otro pasaje y seguramente haciendo referencia a la misma fuente, nos cuenta Platón una genealogía de dioses que atribuye, con no menor displicencia, a "descendientes de dioses, según afirmaban". El candidato evidente es Orfeo, que era pretendidamente hijo de la Musa Calíope:

Hablar de las demás divinidades (i.e. a excepción de los astros y la tierra) y conocer su linaje es más de lo que podemos, así que hay que dar crédito a los que han hablado antes de ello, que eran descendientes de dioses, según afirmaban, y que de algún modo conocían con claridad a sus antepasados. ... De la Tierra y del Cielo nacieron como hijos Océano y Tetis; de ellos, Forcis, Crono y Rea y los que van con ellos; y de Crono y Rea, Zeus, Hera y todos cuantos sabemos que se llaman sus hermanos (P1. Ti. 40d = "Orfeo" fr. 21 Bernabé).

Hoy parece seguro que ambos pasajes proceden de la teogonía órfica que Damascio llama "Eudemia", porque las noticias que el filosofo neoplatónico conoce de ella proceden del discípulo de Aristóteles. Debemos situar esta versión de la teogonía órfica en torno a los últimos años del s. VI a. C. También sabemos que en ella el papel de divinidad primordial lo asumía la Noche. Lo primero que observamos es que, a diferencia de lo que narra Hesíodo, Océano y Tetis no 
pertenecen a la misma generación que los demás titanes y titánides, sino a una generación anterior, situada entre estos y la pareja Tierra y Cielo. El poeta dice que Océano y Tetis "iniciaron las bodas", probablemente porque no considera que Cielo y Tierra hubieran tenido una relación sexual, de manera semejante a como hemos visto que Hesíodo califica las primeras descendencias como "sin el deseable amor", tal vez como una especie de "escisión". Esta posición privilegiada, aunque no originaria de la pareja Océano - Tetis, obedece probablemente al deseo del poeta órfico de hacer entrar en el cuadro teogónico esbozado por Hesíodo la antigua teogonía conocida por Homero. Aunque Océano y Tetis no conservan la primacía absoluta, el poeta les da una cierta preeminencia como padres de los dioses y de las diferentes realidades del mundo, tras un primer período de reproducción cuasiautomática, división o disociación.

\section{Propuestas filosóficas}

\subsection{Tales de Mileto}

Las propuestas filosóficas comienzan por la que se atribuye a Tales de Mileto, sobre la que apenas sabemos nada. Nuestra información depende casi en exclusiva del famoso estado de la cuestión presentado por Aristóteles en Metafísica 983b 9ss. y el dato sobre Tales es muy problemático, ya para el propio Aristóteles, como se ve en su manera de presentar la referencia.

Comienza por un enunciado general en el que sistematiza las ideas de varios presocráticos introduciéndolos en un esquema común:

La mayoría de los primeros filósofos consideró que los principios de todas las cosas eran solo los que tienen aspecto material. En efecto, aquello a partir de lo cual existen todos los seres y a partir de lo cual nacen al principio y en lo que perecen al final, permaneciendo su entidad, pero alterándose en sus accidentes, eso dicen que es el elemento y ese el principio de los seres, y por ello creen que nada nace ni perece, en la idea de que tal naturaleza se conserva siempre.

La presentación es del todo anacrónica, en tanto que está plagada de conceptos aristotélicos: "materia" (byle), "entidad" (ousia), "accidentes" (pathe), "elemento" (stoicheion), incluso "naturaleza” (physis). Es claro que Aristóteles ha adaptado las formulaciones arcaicas a su propio lenguaje filosófico.

Además, presenta las cosas como si Tales, Anaximandro y Anaxímenes, de los que va a hablar a continuación, tuvieran un idéntico esquema ideológico, que "rellenaran" con una arche diferente. Algo de lo que no estamos seguros.

Continúa Aristóteles, unas líneas más abajo (983b 19) refiriéndose a Tales:

En cuanto al número y la forma de tal principio, no todos dicen lo mismo, sino 
que Tales, el iniciador de este tipo de filosofía, afirma que es el agua, por lo que también declaró que la tierra está sobre el agua.

Aristóteles da por supuesto que Tales es iniciador de este tipo de filosofía (se entiende que la que postula que los principios de las cosas tienen aspecto material). Siguen las dos afirmaciones básicas que el Estagirita le atribuye: "el principio es el agua” y "la tierra está sobre el agua”. Esta segunda afirmación la reitera en otro pasaje, Cael. 294a 28, en el que la critica fuertemente con la simple pregunta de “¿y sobre qué se sostiene el agua?”. Una buena pregunta, sin duda.

Se ha suscitado también una gran discusión acerca de si Tales realmente postuló todo lo que dice Aristóteles o se limitó a hacer una afirmación más simple, como "todas las cosas vienen del agua”. Si fuera así, Aristóteles, habría interpretado esta simple afirmación como algo más complejo: "todas las cosas consisten en agua", para hacerla entrar en el esquema al que acabo de referirme. $\mathrm{Y}$ sobre todo tenemos razones para dudar de que Tales postulara que en un determinado momento todas las cosas tornaran a ser agua.

Sea como fuere, parece que el centro de interés del Estagirita no son los detalles sobre cómo el agua se relaciona con las cosas separadas del mundo, ni si ese retorno se produce o no, sino los motivos por los que Tales pudo pensar que el agua era el origen de todo:

Concibió tal vez esta suposición por ver que el alimento de todas las cosas es húmedo y porque de lo húmedo nace el propio calor y por él vive. Y es que aquello de lo que nacen es el principio de todas las cosas. Por eso concibió tal suposición, además de porque las semillas de todas las cosas tienen naturaleza húmeda y el agua es el principio de la naturaleza para las cosas húmedas (Arist. Met. 983b 22).

Debe observarse que Aristóteles dice "concibió tal vez esta suposición”, luego no se refiere a algo que ha leído u oído decir que dijo Tales, sino a los motivos que él supone que pudieron llevar al milesio a hacer tal afirmación. Y señala dos, ambos referidos al valor del agua en relación con la simiente, que tiene naturaleza húmeda.

Simplicio (in Phys. 23.21 Diels) continúa sobre las huellas de Aristóteles para añadir otro posible motivo por el que Tales pudo hacer tal afirmación: que "las cosas que se mueren se secan".

En la continuación del pasaje citado, Aristóteles añade una curiosa noticia que Snell ${ }^{7}$ cree procedente de la colección de "paralelos" de Hipias:

\footnotetext{
${ }^{7}$ Snell 1944: 177.
} 
Hay algunos que piensan que ya los más antiguos y muy alejados de la generación actual, aquellos que fueron los primeros en tratar de los dioses, tuvieron tal opinión acerca de la naturaleza. En efecto, consideraron a Océano y Tetis padres de la generación divina y tuvieron como testigo del juramento de los dioses al agua, la llamada por ellos Éstige (Arist. Met. 983b 22).

Probablemente con la frase "aquellos que fueron los primeros en tratar de los dioses” se refiere a Homero y a Orfeo. Por último, parece que muestra dudas sobre alguna parte de esta afirmación:

Ahora bien, que esta opinión acerca de la naturaleza sea realmente arcaica y antigua, no resultaría demasiado claro

(Arist. Met. 983b 33).

Se puede discutir lo que quiere decir Aristóteles ${ }^{8}$, pero parece que duda de que se pueda remontar a Homero y a un Orfeo cuya autoría le resulta problemática, la interpretación del agua como arche.

$\mathrm{El}$ hecho es que también nosotros podemos preguntarnos las razones por las que Tales postuló que el agua era el origen de las cosas. A las que propone Aristóteles podríamos añadir la condición del agua como masa material sin límites internos, su aparente capacidad para generar vida y su profunda versatilidad para el cambio (moverse, evaporarse, hacerse nube, congelarse). En cuanto a los orígenes míticos, son más que posibles y podemos, además, buscarlos en otra dirección, fuera de Grecia.

En efecto, Plutarco ${ }^{9}$ y Simplicio $^{10}$ señalan un posible origen egipcio para las teorías, no solo de Tales, sino también de Homero. En efecto, ya desde hace tiempo se ha señalado la existencia de un mito egipcio, el de $\mathrm{Nu}$, masa líquida primordial, en cuyas infinitas profundidades se agitaban, confusos, los gérmenes de las $\operatorname{cosas}^{11}$, e imágenes semejantes se encuentran en otras literaturas ${ }^{12}$. En el mundo egipcio esta visión del agua procede verosímilmente de la conversión en mito de la espectacular experiencia de la crecida del Nilo, que convierte tierras resecas en tierras fértiles que se pueblan de árboles y plantas.

\footnotetext{
${ }^{8}$ Remito a Mansfeld 1985: 116 sobre posibles sentidos de la frase.

${ }^{9}$ Plu. Is. et Os. 364C: "Creen que también Homero, como Tales, considera al agua principio y género de toda cosa por haberlo aprendido de los egipcios".

${ }^{10}$ Simpl. in Cael. 522.14: "Aristóteles se opone a esta opinión quizá más bien prevalente porque también entre los egipcios se dice así en forma de mito y Tales quizá trajo su propuesta de ellos".

${ }^{11}$ Por ejemplo, Hölscher 1953.

${ }^{12}$ Por citar casos más conocidos, varios pasajes de los Salmos en que la tierra flota sobre el agua $24.2,104.3,136.6$, etc.
} 
Pero para tener una idea cumplida del alcance de las propuestas de Tales queda por revisar un último texto, un testimonio más de Aristóteles:

Algunos dicen que el alma se halla entreverada en el todo. Posiblemente es ese el motivo por el que Tales pensó que todo está lleno de dioses

(Arist. De An. 411a 7).

La afirmación del filósofo parece querer indicar que Tales concebía una materia animada por un principio activo del movimiento, que identifica aquí con los dioses, pero al que en otro pasaje llama "alma":

Parece que Tales por lo que se cuenta, supuso que el alma es algo que produce movimiento, si es que dijo que la piedra (imán) tiene alma porque mueve el hierro (Arist. De An. 405a 19).

No tenemos que decidir si Tales hablaba de dioses o de almas. En su concepción parece que entendía que había un alma divina que permea el mundo como principio activo, responsable de la vida, del movimiento y de los cambios del agua primordial.

\subsection{Jenófanes}

Los postulados "físicos" de Jenófanes de Colofon presentan problemas, lo cual no es de extrañar, dado que Sexto Empírico ( $M$. 10.313-314) nos indica que tampoco los griegos de su época los tenían claros. En efecto, señala cómo algunos atribuyen a Jenófanes la generación a partir de la tierra, basándose en el fr. B 27 de este autor:

De la tierra nace todo y en tierra todo acaba.

Mientras que otros pretenden que Jenófanes postula dos elementos, apoyándose en el fr. B 33:

Pues todos de la tierra y del agua hemos nacido.

También, Filópono (in Ph. 125.27 Vitelli) nos informa de que Porfirio se alinea de parte de quienes atribuyen a Jenófanes una propuesta basada en dos elementos, sobre la base del fragmento B 29:

Tierra y agua es todo cuanto nace y crece.

Parece claro que Jenófanes consideraba que agua y tierra son los componentes 
de todo lo que se genera y crece. El poeta filósofo elevó la vieja idea de los hombres modelados del barro y que aún podríamos admitir en (B 33) a la categoría de explicación sobre el origen de todos los seres a partir de dos elementos matrices de la vida ${ }^{13}$.

El fragmento B 30 ofrece una explicación algo más larga:

Fuente del agua es el mar, fuente del viento, pues ni habría viento sin el gran mar, ni corrientes de los ríos, ni agua llovediza del éter, y es que el gran mar es quien genera las nubes, los vientos y los ríos.

Este texto nos lleva a concluir que Jenófanes imaginó un mundo compuesto de tierra, firme, que dota de estabilidad al mundo, y de agua, el elemento cambiante por naturaleza. Es el agua la que sufre cambios que pueden advertirse, se evapora se condensa en nubes que, en una condensación mayor, pueden producir fuego, el arco iris o el fuego de San Telmo. Coincide con esta visión la noticia de que Jenófanes (A 33) dedujo de la existencia de fósiles de animales marinos tierra adentro que la tierra estuvo cubierta por mar durante un tiempo y que ha habido alternativas de más o menos agua en la tierra. Por su parte, las plantas y los seres humanos, hechos de agua y tierra, nacen de la tierra y vuelven a la tierra.

\subsection{Empédocles y Anaxágoras}

En este punto debo ser muy breve; Empédocles, obligado por la crítica parmenídea, deshace el origen único y sitúa el agua como principio, pero no como el único, sino como uno de cuatro (los otros tres son aire, fuego y tierra), que comparte con ellos el atributo de la eternidad.

Anaxágoras hace más técnica su materia. No postula cuatro elementos, sino múltiples. El agua pierde todo su protagonismo, al convertirse en un ingrediente más de los centenares que componen su materia mixta, pero esta materia comparte con el agua su carácter fluctuante, mezclado. Frente a los dioses que pueblan el agua de Tales, Anaxágoras habla de un solo principio inteligente, al que llama el Nous, el Intelecto, que gobierna las transformaciones de la materia.

\section{ReFormulaciones míticas}

\subsection{La teogonía órfica de Jerónimo y Helanico}

En el siglo II a. C. reaparecen las reformulaciones míticas en la llamada teogonía órfica de Jerónimo y Helanico. Nos han llegado dos testimonios indirectos

\footnotetext{
${ }^{13}$ Lesher 2001: 132.
} 
de cómo se narraba en ella el principio del proceso cosmogónico:

La Teogonía órfica transmitida por Jerónimo y Helanico ... dice así: desde el principio hubo agua y la materia de la que se cuajó la tierra, siendo estos los principios que supone los primeros (Dam. Pr. 123 bis.= Orph. fr. 75 I Bernabé)

Orfeo también afirma un origen primero a partir del agua.

...Fue en efecto el agua el principio de todas las cosas y del agua se formó fango (Athenag. Leg. 18.3 = Orph. fr. 75 I Bernabé).

Se postulaba en este poema una unidad en el principio, el agua, de la que, como primera transformación, se cuaja o coagula barro. Se ha pretendido que las fuentes que nos han transmitido indirectamente el fragmento, Damascio y Atenágoras, habrían traducido a términos "modernos" los nombres míticos que habría en el poema, de forma que agua y barro serían en el poema Océano y Gea ${ }^{14}$ o bien Océano y Tetis ${ }^{15}$. Pero debemos rechazar la idea ${ }^{16}$ : Damascio, en todo su largo informe sobre las cosmogonías antiguas, nunca sustituye los nombres míticos por nombres comunes, de forma que, si aquí se hubiera hablado de Océano y Tetis o de Océano y Gea, Damascio los habría mencionado por sus nombres, mientras que si nos dice que se hablaba inicialmente de agua, es que se hablaba de agua y no de otra cosa. En ello coinciden, además, su testimonio y el de Atenágoras, que son claramente independientes el uno del otro y sería poco verosímil que los dos hubieran optado por separado por una misma trasposición de nombres. También está claro que, frente a Jenófanes, el autor de esta cosmogonía no habla de dos seres primordiales -en eso Atenágoras es clarísimo- sino de uno solo, agua calificada, agua cenagosa. Rudhardt ${ }^{17}$ ve en la expresión "agua y la materia" una hendíadis por "agua cualificada, cargada de lo que se sedimentará más tarde en forma de tierra”.

De agua y tierra, asexuados y que no forman una pareja, se forma un primer ser con forma de dragón, el Tiempo, y junto a él aparece un segundo ser, Necesidad, llamada también Adrastea, cuyos brazos se extienden por todo el mundo, tocando sus confines ${ }^{18}$. La presencia de Necesidad junto a Tiempo significa que la ordenación del mundo supone dos premisas: la aparición de Tiempo y que el trascurso del tiempo sea un trascurso ordenado, que tenga que producirse de una

\footnotetext{
${ }^{14}$ Jaeger 1952: 253 n. 57.

${ }^{15}$ West 1983: 184ss.

${ }^{16}$ Cf. ya Bernabé 1994.

${ }^{17}$ Rudhardt 1971: 15.

${ }^{18}$ Orph. fr. 74-77 Bernabé.
} 
determinada manera y no de otra. Se trata de una idea que también manifiesta Anaximandro (B 1 D.-K.) "según la necesidad, según la disposición del Tiempo”.

\section{INTERPRETACIONES FILOSÓFICAS DE PROPUESTAS MÍTICAS}

\subsection{Interpretación estoica de Caos}

Por último, como muestra de interpretación filosófica de un poeta antiguo (como la que conocemos muy ampliamente en el papiro de Derveni), en el terreno de las aguas primordiales, contamos con un testimonio referido a Zenón el estoico. Los estoicos, en especial Crisipo, mostraron un constante interés en demostrar que sus postulados procedían de la más remota antigüedad, lo que los llevaba a buscar coincidencias con sus propias doctrinas en Homero, Hesíodo o la tradición órfica ${ }^{19}$. Veamos el testimonio de Zenón:

Y Zenón afirma que el Caos de Hesíodo es agua, que una vez encogida se convierte en barro, apretado el cual se solidifica en tierra

(Sch. A. R. 1. 496-498b = SVF 1.29.17).

Es evidente que Zenón le aplica a Hesíodo el procedimiento evolutivo de Anaxímenes, pero ¿por qué considera que es agua? La respuesta nos la da un texto de Filón:

Aristóteles piensa que Caos es el espacio ... pero algunos estoicos piensan que es el agua, creyendo que el nombre se ha configurado en relación con "líquido" (Phlp. Aet. 225.5).

Los estoicos fundamentaron su propuesta en una relación etimológica de chaos con cheo "derramar", de modo que, con el escaso rigor con el que los antiguos utilizaban las etimologías, el Casos debía tratarse de agua.

\section{Conclusiones}

\subsection{Razones de un modelo}

Naturalmente solo podemos especular sobre este punto, pero lo haremos basándonos en los motivos que verosímilmente han podido propiciar estas propuestas. Hay varios aspectos del agua que excitan la imaginación a la hora de situarla en el origen de las cosas:

a) Si hay que partir de un elemento inicial, no parece adecuado que tenga una forma muy definida ni muy sólida, porque resulta así más difícil de imaginar su

\footnotetext{
${ }^{19}$ Cf. Casadesús 2005, 2008.
} 
transformación en otras materias y en los muy diversos seres que componen el mundo. Así pues, resulta más adecuada una materia que, como el agua, carezca de forma definida, porque de lo que es carente de forma se pueden conformar todas las cosas. En la mitología griega, los seres marinos (Tetis, Nereo, el Viejo del Mar) presentan siempre formas cambiantes.

b) Además de su carencia de forma, susceptible de adoptar configuraciones diversas, el agua parece estar en perpetuo movimiento y este parece proceder de sí misma; el agua en grandes masas, en especial en la imagen mas característica del agua, el mar, es la materia que más parece un ser vivo y da la impresión de que se mueve por sí misma.

c) En tercer lugar el agua es vista como la sustancia fundamental para la subsistencia. El agua es garante de generar crecimiento y vida. Incluso el agua corrompida parece producir por si misma nuevos seres. Por el contrario, la aridez impide el crecimiento y se asocia con la muerte.

d) La visión griega de las relaciones entre macrocosmos y microcosmos hace que el universo sea imaginado como un ser vivo, cuyo principio vivificador sería el agua (en el caso del mito egipcio ello es perfectamente claro).

e) Desde el principio, este modelo entra en fuerte competencia con otro en el que el principio es el aire (el autor de la Titanomaquia cíclica considera primer principio al Éter, el aire es postulado por Anaxímenes, por Diógenes de Apolonia, y por el Comentarista de Derveni ${ }^{20}$ ), en tanto que vivificador también y relacionable con la respiración, con el alma y con la inteligencia.

f) Junto a esta visión que acabo de esbozar y que puede sugerir por qué se construyen cosmogonías del agua primordial, hay un modelo subyacente distinto que se refiere a los mitos en que se concibe que el hombre está hecho de barro. El agua no es nunca la materia única de la que está hecha el hombre. Es la tierra la primordial. Tierra sola o tierra con agua. Así que no se trata tanto de ver en el agua su carácter de dadora de vida; ese papel lo asume el aire; con frecuencia el dios insufla aire-alma en el ser vivo, cuya manifestación de vida más evidente es la respiración. El proceso mental que subyace a esta explicación parece consistir en que se proyecta a las divinidades el modelo del escultor humano que crea seres con apariencia de hombre o de animales modelando el barro. Pero para fijar este modelado se necesita fuego, que aparece así como otro de los candidatos a ser elemento primordial.

g) Además, el hábito de la inhumación relaciona la tierra con el lugar de descomposición, al que torna el hombre hecho de barro.

h) Todas estas especulaciones irán llevando lentamente a configurar una teoría de los cuatro elementos.

${ }^{20}$ Titan. fr. 1 Bernabé; Anaximen. B 2 D.-K.; Diog. Apoll. fr. 8-9 Laks; P.Derv. col 17. 


\subsection{Líneas evolutivas}

Es hora de presentar sumariamente la evolución de las propuestas que he presentado, siguiendo los criterios que he formulado al principio. La versión de Homero es un relato mítico, protagonizado una pareja primordial de dioses acuáticos: un dios del agua dulce, Océano, y una diosa del agua salada, Tetis. Son el origen de todas las cosas, no solo de la vida. Una querella (neikos), cuyos motivos desconocemos, produce una separación entre ellos que parece dar cuenta de la posterior multiplicidad de los seres (de algún modo es el antecedente del papel de neikos en Empédocles), y se les supone capacidad de moción, en tanto que son dioses. En este mito predomina la concepción generatriz, viva, activa, del agua. Es poco probable que se encuentre en Homero un eco de la configuración de los seres humanos a partir de barro.

Hesíodo restringe el papel de los dioses acuáticos primordiales a un papel secundario, frente a Cielo y Tierra, espacios "sólidos"; ni son origen del mundo ni de la vida; la separación que da origen a las cosas es la de Tierra y Cielo, por intervención de Caos. Por otra parte, se hace eco, aunque de forma parcial, del mito que hace provenir del barro a los seres humanos.

La teogonía órfica Eudemia es otro relato mítico, protagonizado por seres divinos, Océano y Tetis, la misma pareja acuática que mencionaba Homero, que en la versión órfica no son originarios pero ocupan un espacio muy alto en la jerarquía divina, por encima de los titanes, aunque no de Cielo y Tierra, que asumen el papel de pareja originaria. Cielo y Tierra se separan y de ellos se segregan unas aguas primordiales, casi primigenias, en tanto que son los padres de todo el resto de la generación divina. Como si el poeta estimase que las aguas primordiales necesitaban un espacio sólido en el que fijarse. Seguimos hablando de dioses, y por tanto, con capacidad de transformarse por sí mismos.

Se atribuye a Tales una explicación que no conocemos bien, pero de la que podemos suponer con verosimilitud que postulaba como origen de las cosas un agua primordial; prescinde de la pareja mítica y habla solamente de agua, sin nombre, lo que es ya una actitud más filosófica. En principio, si es llamada agua, es materia inerte. Sin embargo, Tales permanece anclado a un pensamiento religioso, en tanto que la supone animada por una especie de almas divinas que están por doquier en ella. No podemos determinar si entiende que estos principios activos pertenecen al agua misma o actúan insertos en ella. Lo que parece claro es que son los principios activos a los que debemos atribuir la capacidad de moción y por ende, la responsabilidad de los cambios. El agua no es solo principio de vida, sino de toda la realidad.

Jenófanes hace una propuesta filosófica en la que parte de dos elementos fundamentales de los que todo procede: tierra y agua. Tierra es el elemento más estable, agua el cambiante, el que se transforma y produce toda clase de fenómenos meteorológicos. Todo parece indicar que las considera puras materias, de 
forma que hemos de pensar que sobre ellas debe actuar ese dios no antropomorfo, puro pensamiento activo, capaz de configurar movimiento a las cosas solo con el poder de su mente, del que nos habla en el fr. B 25:

Sin esfuerzo, con la decisión que le da su entendimiento, todo lo conmueve.

Empédocles acepta una multiplicidad de elementos originarios, cuatro, que son de la misma antigüedad e importancia y que se mezclan o no de acuerdo a la acción de principios activos de signo contrario, Amor y Odio. En Anaxágoras el agua pierde todo el protagonismo, al ser uno de los múltiples ingredientes de la materia única, mientras que el principio activo es el Nous.

Por su parte, en la Teogonía de Jerónimo y Helanico, pese a ser una propuesta mítica, la influencia filosófica se hace muy visible. Las divinidades primordiales aparecen ya como pura materia y las personificaciones que resultan de ella (Tiempo/Necesidad) resultan transparentes.

Por último, Zenón, como buen estoico, trata de encontrar huellas de sus teorías en los autores más antiguos, para prestigiarlas. Y para ello recurre a procedimientos característicos, la etimología y el carácter simbólico. Convierte así el Caos hesiódico en agua primordial.

Al término del recorrido, vemos cómo las propuestas míticas del agua primordial dan lugar a propuestas filosóficas, que influyen en las míticas y que incluso interpretan filosóficamente viejas formulaciones del mito.

\section{BibLIOGRAFía}

Bernabé, A. (1994), "Consideraciones sobre una teogonía órfica”, in Actas del VIII Congreso Español de Estudios Clásicos (Madrid, 23 al 28 de septiembre de 1991). Madrid, 91-100.

Burkert, W. (1992), The Orientalizing Revolution. Near Eastern Influence on Greek Culture in the Early Archaic Age. Cambridge (Mass.).

Casadesús, F. (2005), "Adaptaciones e interpretaciones estoicas de los poemas de Orfeo", in A. Alvar Ezquerra y J. F. González Castro (eds.), Actas del XI Congreso Español de Estudios Clásicos, I. Madrid, 309-318.

Casadesús, F. (2008), “Orfismo y estoicismo”, in A. Bernabé y F. Casadesús (eds.), Orfeo y la tradición órfica: un reencuentro. Madrid, 1307-1338.

Cunchillos, J.-L. (1990), Los orígenes. Madrid.

Gladstone, W. E. (1890), Landmarks of Homeric Study. London.

Hölscher U. (1953), "Anaximander und der Anfang der Philosophie”, Hermes 81: 257-277 y 385-418.

Jaeger W. (1952), La teología de los primeros filósofos griegos. México. 
King, L. W. (1902), Enûma Eliš: The Seven Tablets of Creation. London.

Lambert, W. C. y Parker, S. B. (1966), Enûma Eliš. The Babylonian Epic of Creation. Oxford.

Lara Peinado, F. (2008), Enuma Elish. Poema babilónico de la creación. Madrid, 2a ed.

Lesher, J. H. (2001), Xenophanes of Colophon. Fragments. Toronto.

Mansfeld, J. (1985), "Aristotle and Others on Thales, or the Beginning of Greek Philosophy", Mnemosyne ser. 4, 38: 109-129.

Martínez Nieto, R. B. (2000), La aurora del pensamiento griego. Las cosmogonías prefilosóficas de Hesiodo, Alcmán, Ferecides, Epiménides, Museo y la teogonía órfica antigua. Madrid.

Rudhardt, J. (1971), Le thème de l'eau primordiale dans la mythologie grecque. Berne.

Snell, B. (1944), "Die Nachrichiten über die Lehren des Thales un die Anfänge der griechischen Philosophie- und Literaturgeschichte", Philologus 96,3: 170-182.

West, M. L. (1983), The Orphic Poems. Oxford. 